\title{
Simulation of Performance of Cadmium Telluride Solar Cell Using AMPS-1D Program
}

\author{
Hamdan A. S. Al-shamiri ${ }^{1,2,}$, Mohamed O. Sid-Ahmed ${ }^{3}$, Faisal Abdu Hezam ${ }^{4}$ \\ ${ }^{1}$ physics Department, Faculty of Applied Science, Taiz University, Taiz, Republic of Yemen \\ ${ }^{2}$ physics Department, Faculty of science and Arts, Bisha University, Bisha, Saudi Arabia \\ ${ }^{3}$ Physics Department, Faculty of Science, Sudan University of Science \& Technology, Khartoum, Republic of Sudan \\ ${ }^{4}$ Physics Department, Faculty of Education, Taiz University, Taiz, Republic of Yemen
}

Email address:

h_elshamiri@hotmail.com (H. A. S. Al-shamiri)

*Corresponding author

\section{To cite this article:}

Hamdan A. S. Al-shamiri, Mohamed O. Sid-Ahmed, Faisal Abdu Hezam. Simulation of Performance of Cadmium Telluride Solar Cell Using AMPS-1D Program. Journal of Photonic Materials and Technology. Vol. 2, No. 2, 2016, pp. 14-19. doi: 10.11648/j.jmpt.20160202.11

Received: September 2, 2016; Accepted: September 23, 2016; Published: October 17, 2016

\begin{abstract}
In this research, we have used the AMPS-1D program to study the enhancement of the Cadmium telluride cell efficiency by studying the relationship between efficiency and some variables, such as the thickness and doping density of the cell layers, type of the back contact metal, and changes in solar radiation and temperature. Simulation results showed that the efficiency increased largely with the increase in the thickness of the absorbent layer CdTe, until the value of (1500 nm), by reducing the thickness of the layer of CdS (n-type), and it does not depend on the thickness of the front contact layer $\left(\mathrm{SnO}_{2}\right)$. The efficiency depends largely on the doping concentration of the absorbent layer $\left(\mathrm{N}_{\mathrm{A}}\right)$. When the efficiency increases with vaccination rate up to the value $10^{16} \mathrm{~cm}^{-3}$, then it does not increase significantly, while a higher efficiency is reached when the vaccination of $\mathrm{CdS}$ layer is at the value $10^{17} \mathrm{~cm}^{-3}$. The cell has a high stability at high temperatures with a decreasing rate of $0.08 \% /{ }^{\circ} \mathrm{C}$. The efficiency depends on the type of metal used as a back contact material in the cell under study, and showed that the Aluminum (Al) gives higher efficiency than other metals. As a result installation of Cadmium telluride cell by adoption of the values obtained increases the efficiency of the cell from $13.8 \%$ to $19.5 \%$.
\end{abstract}

Keywords: Thin Film Solar Cell, Cadmium Telluride Cell Efficiency, Simulation, AMPS 1D

\section{Introduction}

The CdTe thin film solar cell basically consists of two semiconducting layers. A CdS layer serves as the n-type window material with energy bandgap, $\mathrm{Eg}=2.42 \mathrm{eV}$ and a CdTe layer (absorber) deposited on top with $\mathrm{Eg}=1.45 \mathrm{eV}$. Research in CdTe dates back to the 1950s. A CdS/CdTe thin film solar cell was first fabricated using an evaporation technique in 1969 by Adrirovich et al. [1] with a conversion efficiency of $1 \%$. In the late of 1980s [2], Tyan and Perez produced a solar cell with an efficiency of $10 \%$ based on a $\mathrm{CdS} / \mathrm{CdTe}$ thin film. Afterwards an efficiency of $15.8 \%$ has been reached by Ferekides et al. [3]. At present, the CdTe solar cell makes more attraction to the researchers and commercials for its higher efficiency, low cost, highly stable and large scale fabrication opportunity. CdTe has larger absorption coefficient $\left(>5 \times 10^{5} \mathrm{~cm}^{-1}\right)$ due to its ideal and direct band gap energy $1.45 \mathrm{eV}$; which corresponds well to sunlight spectra and $\sim 99 \%$ of photons with energy greater than the band gap $\left(E_{g}\right)$ can be absorbed within $1 \mu \mathrm{m}$ of CdTe film $[4,5,6]$. Small-area CdTe cells already achieved efficiency of $16.5 \%$ in laboratory and $11 \%$ in the commercial modules. However, there are scopes to improve the $\mathrm{CdS} / \mathrm{CdTe}$ solar cell performance further more by modified design and simple deposition technique to improve any one of cell output parameters [7]. The strategies for improving cell performance have been explored, utilizing AMPS-1D (Analysis of Microelectronic and Photonic Structures) simulator have also been discussed $[8,9]$.

The AMPS-1D program has been developed for pragmatically simulate the electrical characteristics of thin film hetero-junction solar cells. It has been proven to be a 
very powerful tool in understanding device operation and physics for single crystal, poly-crystal and amorphous structure. To date, more than 200 groups worldwide have been using AMPS-1D for solar cell design [8].

The objective of this research is to use AMPS-1D program (analysis of microelectronic and photonic structure in one dimension) to obtain the optimum structure of the cadmium telluride solar cell $(\mathrm{CdS} / \mathrm{CdTe})$.

\section{Modeling and Simulation}

The major objectives of numerical modeling and simulation in solar cell research are testing the validity of

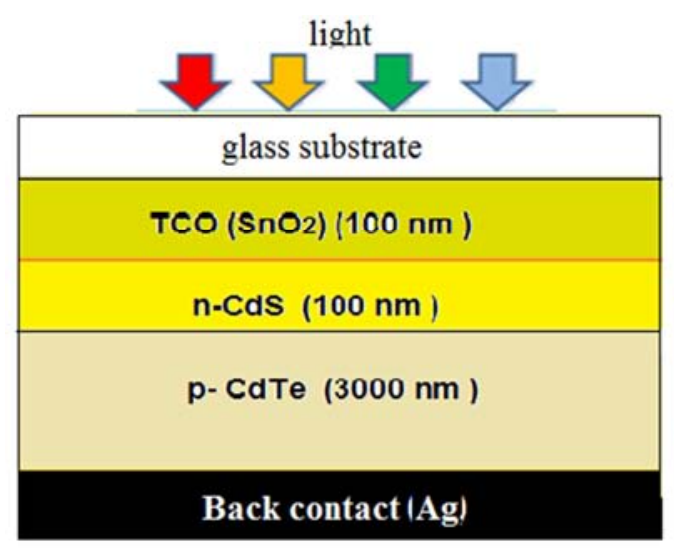

proposed structures and geometry on cell performance and fitting of modeling output to experimental results. Fig. 1a and 1b illustrates the CdTe baseline case structure and the modified (Glass/SnO $/ 2 / \mathrm{CdS} / \mathrm{CdTe} / \mathrm{Al}$ ) structure of $\mathrm{CdTe}$ cell for higher conversion efficiency $(\eta)$. The baseline case cell in this work contains of three principle layers: $\mathrm{n}$-type $\mathrm{SnO}_{2}$ as a TCO material (high transparence, high conductivity), n-type $\mathrm{CdS}$ as a window layer and p-type CdTe as an absorber layer. Considering the low cost feature $\mathrm{Ag}$ is used as a back contact material with back contact barrier height $\left(\Phi_{\mathrm{bL}}\right)$ of $1.25 \mathrm{eV}$. Figures $1 \mathrm{a}, 1 \mathrm{~b}$ illustrate the baseline case of $\mathrm{CdS} / \mathrm{CdTe}$ cell and the modified structure for higher conversion efficiency $(\eta)$.

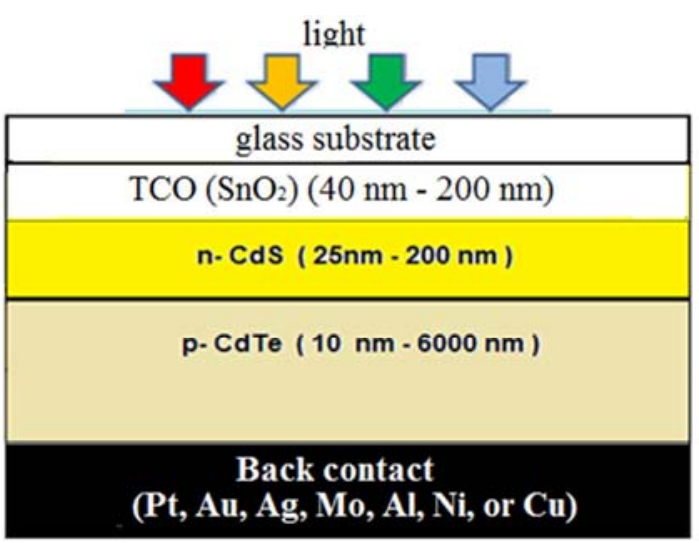

Figure 1. Structures of the CdS /CdTe solar cell: (a) conventional baseline case structure and (b) modified structure for higher performance.

In this analysis, we have varied the CdTe layer thickness from $10 \mathrm{~nm}$ up to $6000 \mathrm{~nm}, \mathrm{CdS}$ window layer thickness from $25 \mathrm{~nm}$ to $600 \mathrm{~nm}$ and $\mathrm{SnO}_{2}$ layer thickness from $10 \mathrm{~nm}$ to $200 \mathrm{~nm}$ and with different back contact materials; such as $(\mathrm{Pt}, \mathrm{Au}, \mathrm{Ag}, \mathrm{Mo}, \mathrm{AL}, \mathrm{Ni}$ and $\mathrm{Cu}$ ) and by keeping all other parameters at fixed value as shown in table 1 aiming to efficient and thinner $\mathrm{CdS} / \mathrm{CdTe}$ solar cell.

Table 1. Material parameters used for cell simulation.

\begin{tabular}{llll}
\hline & $\mathbf{n - S n O} \boldsymbol{O}_{2}$ & $\boldsymbol{n}$-CdS & $\boldsymbol{p}$-CdTe \\
\hline$W(\mu \mathrm{m})$ & $0.01-0.50$ & $0.025-0.6$ & $0.010-6$ \\
$\varepsilon / \varepsilon_{o}$ & 9 & 10 & 9.4 \\
$\mu_{e}\left(\mathrm{~cm}^{2} / v_{s}\right)$ & 100 & 350 & 500 \\
$\mu_{h}\left(\mathrm{~cm}^{2} / v_{s}\right)$ & 25 & 50 & 60 \\
$E_{g}(\mathrm{eV})$ & 3.6 & 2.42 & 1.45 \\
$N_{C}\left(\mathrm{~cm}^{3}\right)$ & $2.2 \times 10^{18}$ & $2.2 \times 10^{18}$ & $7.5 \times 10^{17}$ \\
$N_{V}\left(\mathrm{~cm}^{3}\right)$ & $1.8 \times 10^{19}$ & $1.8 \times 10^{19}$ & $1.8 \times 10^{18}$ \\
$\chi(\mathrm{ev})$ & 4.5 & 4.5 & 4.28 \\
$N_{A}\left(\mathrm{~cm}^{-3}\right)$ & ------- & ------- & $5 \times 10^{16}$ \\
$N_{D}\left(\mathrm{~cm}^{-3}\right)$ & $10^{17}$ & $10^{18}$ & ------- \\
\hline
\end{tabular}

\section{Results and Discussion}

\subsection{Effects of Layer Thickness}

The effects of $\mathrm{Cds}, \mathrm{CdTe}$ and $\mathrm{SnO}_{2}$ thickness on the conversion efficiency of the solar cell were studied. The conventional CdTe baseline structure (glass $/ \mathrm{SnO}_{2} / \mathrm{CdS} / \mathrm{CdTe} / \mathrm{Ag}$ ) was the starting point of this analysis. The conversion efficiency of $13.78 \%$ (Open circuit voltage $(V o c)=0.83 \mathrm{~V}$, Short circuit current density $\left(J_{S c}\right)=$ $25.035 \mathrm{~mA} / \mathrm{cm}^{2}$, Fill factor $(F F)=0.66$ ) was found from the baseline case structure (figure 1a); where CdTe thickness was $5000 \mathrm{~nm}, \mathrm{SnO}_{2}$ was $500 \mathrm{~nm}, \mathrm{CdS}$ was $100 \mathrm{~nm}$, and $\mathrm{Ag}$ was taken as the final back contact metal with a barrier height of $1.25 \mathrm{eV}$, when the temperature is fixed at a value of $300 \mathrm{~K}$ and with the CdTe doping concentration $\left(10^{15}\right) \mathrm{cm}^{-3}$, CdS doping concentration $\left(10^{18}\right) \mathrm{cm}^{-3}$, the other conditions and parameters that applied in the simulation were given in table 1 .

The CdS thickness has been varied from $25 \mathrm{~nm}$ to $600 \mathrm{~nm}$ to explore thinner window layer and the results obtained from AMPS-1D simulation are shown in figure 2.

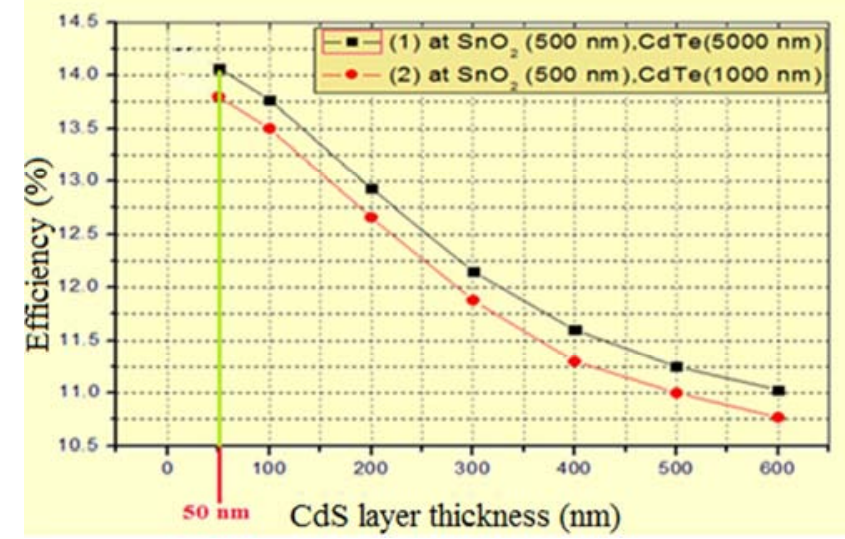

Figure 2. Relation between CdS layer thickness and the conversion efficiency of the baseline case cell at different thicknesses of CdTe layer. 
Figure 2 shows that efficiency improved greatly with reduced CdS layer, the cell conversion efficiency increases when the CdS layer thickness is reduced. But from the other published works $[10,11,12]$ to date; it is impractical to fabricate cells with CdS film thickness below $50 \mathrm{~nm}$. It is found that when the operating wavelength is below $510 \mathrm{~nm}$ the quantum efficiency (QE) was significantly affected with increasing CdS layer thickness. This affected mainly on $J_{S C}$ and finally the conversion efficiency of the cell. Considering the fabrication constraint, the CdS film thickness of $50 \mathrm{~nm}$ was selected with conversion efficiency of $14.08 \%(V o c=0.83 \mathrm{~V}$, $J_{S c}=25.46 \mathrm{~mA} / \mathrm{cm}^{2}, \mathrm{FF}=0.664$ ) (figure 2). This result is in a good agreement with other published works $[10,11]$.

To explore the thickness of CdTe absorber layer required to achieve maximum conversion efficiency; the CdTe absorber thickness was varied from $10 \mathrm{~nm}$ to $6000 \mathrm{~nm}$ to explore thinner CdTe absorber layer using AMPS-1D simulator, the simulated results are shown in figure 3 . It is clear from figure 3 that the solar cell output efficiency is maximum for CdTe thickness greater than $2000 \mathrm{~nm}$, and the efficiency decreases sharply below the CdTe thickness of $1500 \mathrm{~nm}$; this indicates that $1.5 \mu \mathrm{m}$ thickness of CdTe layer is sufficient to get a high efficiency. This value close to the theoretical minimum thickness $(2 \mu \mathrm{m})$ required for CdTe layer to absorb $99 \%$ of the incident photons with energy greater than $\mathrm{Eg}[11]$. The $1.5 \mu \mathrm{m}$ thick CdTe cell shows efficiency of $14.5 \%$, (at conditions in figure 3 ). These results are in a good agreements with related published results [10, $11,12,13]$.

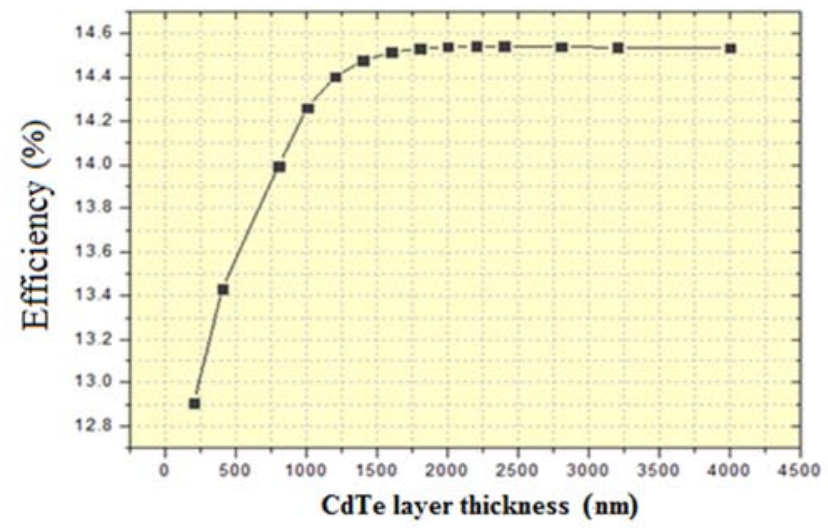

Figure 3. Effect of CdTe film thickness on the cell conversion efficiency at $300 \mathrm{~K}, \mathrm{CdS}$ with $100 \mathrm{~nm}$ thickness.

The effect of the TCO layer $\left(\mathrm{SnO}_{2}\right)$ thickness on the cell conversion efficiency has been studied using AMPS-1D program. The TCO layer thickness was varied from $40 \mathrm{~nm}$ to $200 \mathrm{~nm}$ at $300 \mathrm{~K}$, with $100 \mathrm{~nm}$ thickness for CdS layer, 1000 $\mathrm{nm}$ thickness for CdTe layer, while all parameters were fixed as shown in table 1 .

Figure 4 shows the results obtained from AMPS simulation which indicate that the conversion efficiency is unaffected by TCO $\left(\mathrm{SnO}_{2}\right)$ layer thickness (remains constant at the value $14.12 \%$ ), so the reduced value $100 \mathrm{~nm}$ for TCO layer thickness will be suitable.

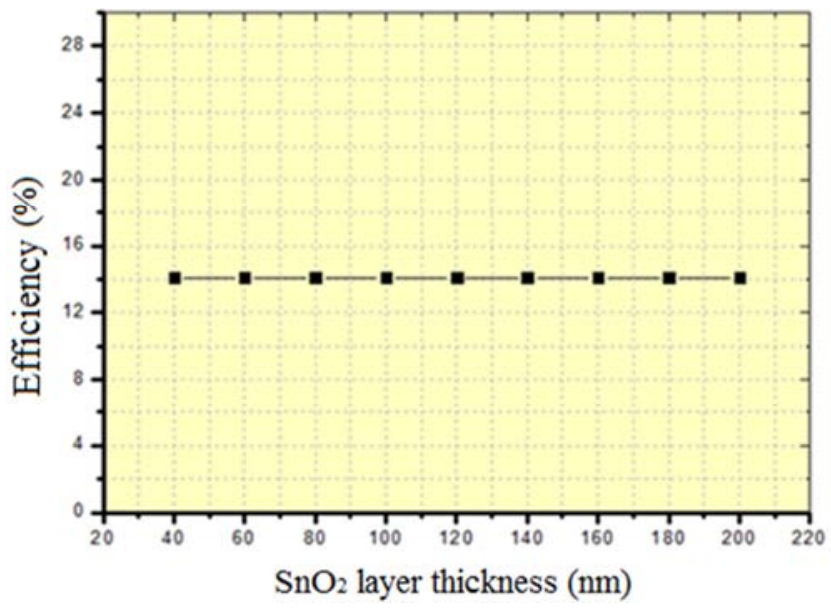

Figure 4. Effect of the TCO layer $\left(\mathrm{SnO}_{2}\right)$ thickness on the cell conversion efficiency.

\subsection{Effects of Doping Concentration}

In the baseline case cell CdTe layer doping concentration was $\left(10^{15} \mathrm{~cm}^{-3}\right)$ with a conversion efficiency $14.12 \%$ (Voc $=$ $0.85 \mathrm{~V}, J_{S C}=25.27 \mathrm{~mA} / \mathrm{cm}^{2}, \mathrm{FF}=0.66$ ); (donor doping density $\left(\mathrm{N}_{\mathrm{D}}\right)$ of $\mathrm{CdS}$ layer was fixed at the value $\left.\left(10^{18} \mathrm{~cm}^{-3}\right)\right)$. It has been found that the conversion efficiency increases up to $16.2 \%\left(V o c=0.97 \mathrm{~V}, J_{S c}=24.89 \mathrm{~mA} / \mathrm{cm}^{2}, \mathrm{FF}=0.66\right)$ with the CdTe doping density $\left(10^{16} \mathrm{~cm}^{-3}\right)$, (at the thickness values $100 \mathrm{~nm}, 50 \mathrm{~nm}, 1000 \mathrm{~nm}$ of $\mathrm{SnO}_{2}, \mathrm{CdS}$, CdTe layers respectively). Figure 5 shows the effect of acceptor doping density $\left(\mathrm{N}_{\mathrm{A}}\right)$ on the cell efficiency; where the efficiency was calculated at different values of $\mathrm{N}_{\mathrm{A}}$ and found that the conversion efficiency increases with the increase of acceptor doping density $\left(\mathrm{N}_{\mathrm{A}}\right)$. Figure 5 shows that efficiency increases sharply with the increase of $\mathrm{N}_{\mathrm{A}}$ up to $3 \times 10^{15} \mathrm{~cm}^{-3}$, so the concentrations of $3 \times 10^{15} \mathrm{~cm}^{-3}-10^{16} \mathrm{~cm}^{-3}$ will be sufficient to enhance the cell conversion efficiency.

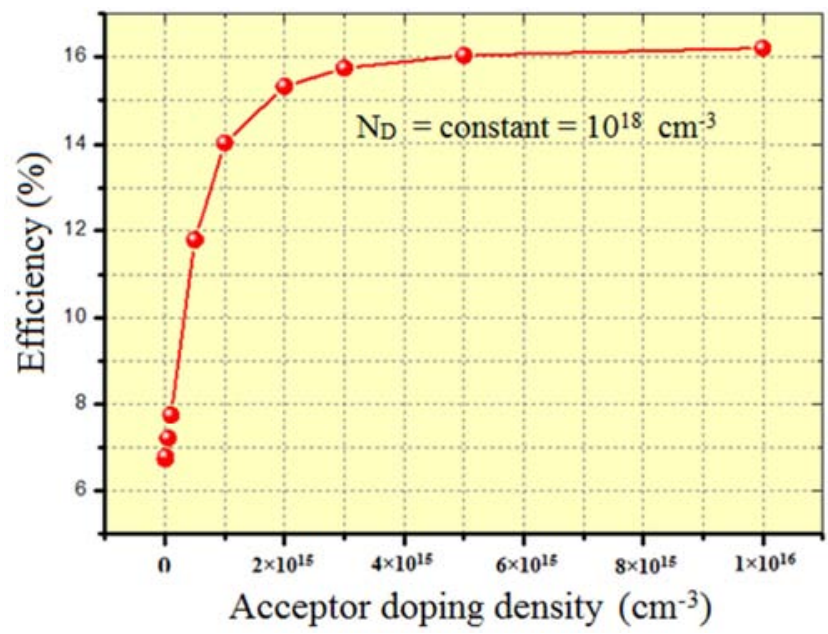

Figure 5. Effect of acceptor doping density ( $\left.N_{A}\right)$ (of CdTe layer) on the efficiency of the baseline case cell (glass $/ \mathrm{SnO}_{2} / \mathrm{CdS} / \mathrm{CdTe} / \mathrm{Ag}$ ), at $\mathrm{N}_{D}=10^{18}$ $\mathrm{cm}^{-3}$. 


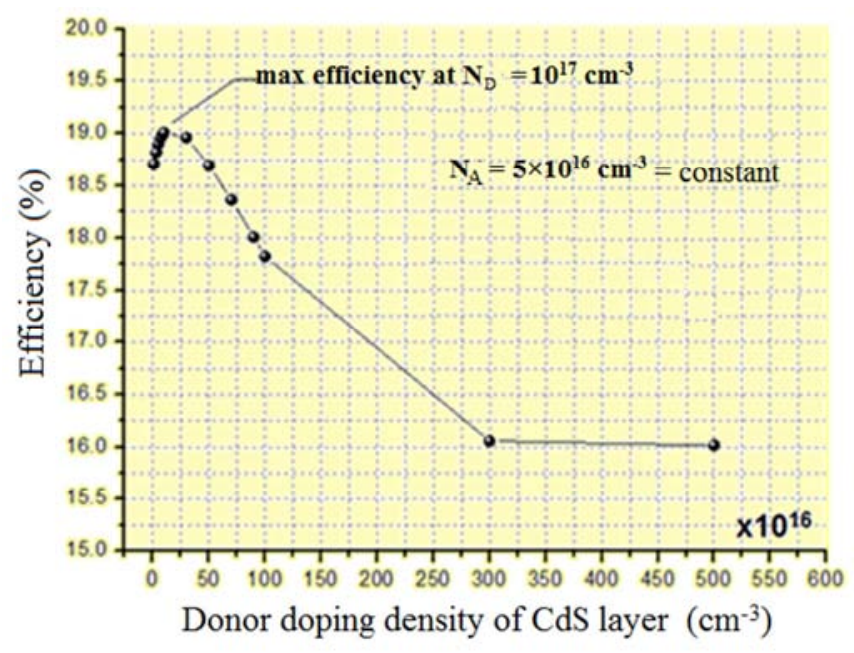

Figure 6. Effect of donor doping density $\left(N_{D}\right)$ (of CdS layer) on the conversion efficiency of the baseline case cell (glass $/ \mathrm{SnO}_{2} / \mathrm{CdS} / \mathrm{CdTe} / \mathrm{Ag}$ ), at $N_{A}=5 \times 10^{16} \mathrm{~cm}^{-3}$.

To investigate the effect of donor doping density $\left(\mathrm{N}_{\mathrm{D}}\right)$ on the cell conversion efficiency, the acceptor doping density $\left(\mathrm{N}_{\mathrm{A}}\right)$ (of CdTe layer) will be fixed at the value $\left(5 \times 10^{16} \mathrm{~cm}^{-3}\right)$ and the efficiency will be calculated as $\left(\mathrm{N}_{\mathrm{D}}\right)$ is changed from $10^{16} \mathrm{~cm}^{-3}$ to $5 \times 10^{18} \mathrm{~cm}^{-3}$, the highest efficiency $19.01 \%$ has been obtained using AMPS-1D program at the value of donor doping density $\left(\mathrm{N}_{\mathrm{D}}\right)$ equal to $10^{17} \mathrm{~cm}^{-3}$. The simulated results are shown in figure 6 and it has been obtained with $50 \mathrm{~nm}$ thickness for CdS layer, $1000 \mathrm{~nm}$ thickness for CdTe layer, while the other parameters were fixed as shown in table 1 .

\subsection{Effect of the Back Contact Barrier height $\left(\Phi_{b L}\right)$}

In the baseline case cell (glass $/ \mathrm{SnO}_{2} / \mathrm{CdS} / \mathrm{CdTe} / \mathrm{Ag}$ ) considering the simplicity and low cost feature silver was used as a back contact material with back contact barrier height $\left(\Phi_{\mathrm{bL}}\right)$ of $1.25 \mathrm{eV}$. To investigate the effect of the back contact barrier heights on the cell conversion efficiency back contact materials ( $\mathrm{Ag}, \mathrm{Ni}, \mathrm{Cu}, \mathrm{Pt}, \mathrm{Al}, \mathrm{Ti}, \mathrm{Zn}, \mathrm{Mo}, \mathrm{Au}$ ) have been inserted in the modified cell; for the (p-type - metal) contact the back contact barrier height is calculated from the relation 1 [14]:

$$
\operatorname{BHIBL}\left(\Phi_{\mathrm{bL}}\right)=\mathrm{CHI}+\mathrm{EG}-\mathrm{WF}
$$

Where:

CHI the electron affinity $(\chi)$, EG the mobility band gap of the p-type material CdTe, WF $\left(\Phi_{\mathrm{m}}\right)$ the metal work function. Table 2 shows the calculated barrier heights for some proposed metals as a back contact and the calculated efficiencies for the corresponding proposed structures of the modified cell.

Table 2. The calculated barrier heights (from equ. 1) and calculated efficiencies using AMPS-1D simnulation program for some proposed structures including different back contact materials.

\begin{tabular}{lllll}
\hline The proposed structures & $\begin{array}{l}\text { Work function range } \\
\text { (metal) }\end{array}$ & Selected values & $\begin{array}{l}\text { Barrier height BHIBL }(\mathbf{e V})= \\
\text { CHI+EG -WF (ev) (Back contact) }\end{array}$ & Efficiency \% \\
\hline $\mathrm{Glass} / \mathrm{SnO}_{2} / \mathrm{CdS} / \mathrm{CdTe} / \mathrm{Pt}$ & $5.12-5.93$ & 5.65 & 0.13 & 1.768 \\
$\mathrm{Glass} / \mathrm{SnO}_{2} / \mathrm{CdS} / \mathrm{CdTe} / \mathrm{Au}$ & $5.1-5.47$ & 5.15 & 0.63 & 10.524 \\
$\mathrm{Glass} / \mathrm{SnO}_{2} / \mathrm{CdS} / \mathrm{CdTe} / \mathrm{Ni}$ & $5.04-5.35$ & 5.1 & 0.68 & 11.517 \\
$\mathrm{Glass} / \mathrm{SnO}_{2} / \mathrm{CdS} / \mathrm{CdTe} / \mathrm{Cu}$ & $4.53-5.1$ & 4.65 & 1.13 & 18.95 \\
$\mathrm{Glass} / \mathrm{SnO}_{2} / \mathrm{CdS} / \mathrm{CdTe} / \mathrm{Mo}$ & $4.36-4.95$ & 4.6 & 1.18 & 18.983 \\
$\mathrm{Glass} / \mathrm{SnO}_{2} / \mathrm{CdS} / \mathrm{CdTe} / \mathrm{Ag}$ & $4.52-4.74$ & 4.53 & 1.25 & 19.01 \\
$\mathrm{Glass} / \mathrm{SnO}_{2} / \mathrm{CdS} / \mathrm{CdTe} / \mathrm{Ti}$ & 4.33 & 4.33 & 1.45 & 19.23 \\
$\mathrm{Glass} / \mathrm{SnO}_{2} / \mathrm{CdS} / \mathrm{CdTe} / \mathrm{Zn}$ & $3.63-4.9$ & 4.33 & 1.45 & 19.23 \\
$\mathrm{Glass} / \mathrm{SnO}_{2} / \mathrm{CdS} / \mathrm{CdTe} / \mathrm{Al}$ & $4.06-4.28$ & 4.28 & 1.5 & $19.5(\mathrm{max})$ \\
\hline
\end{tabular}

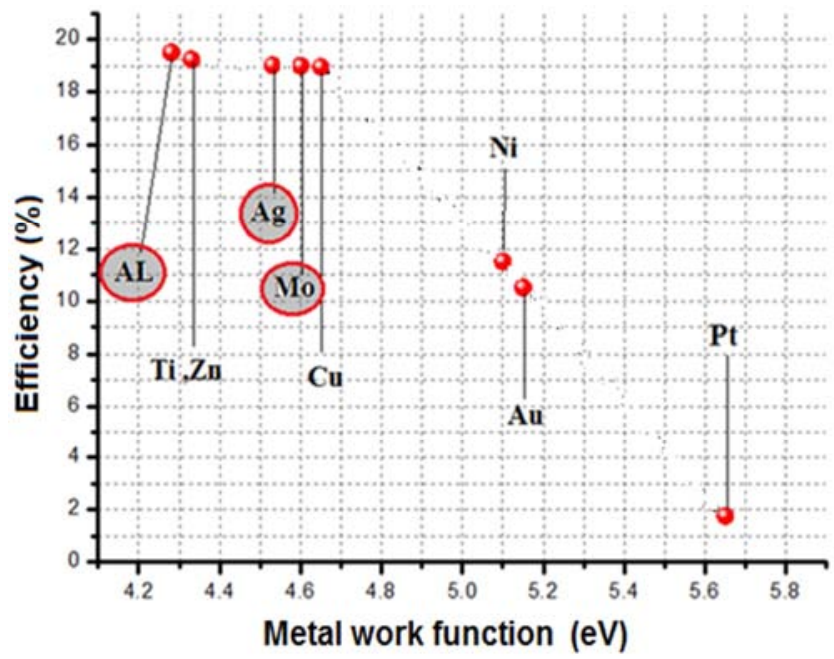

(a)

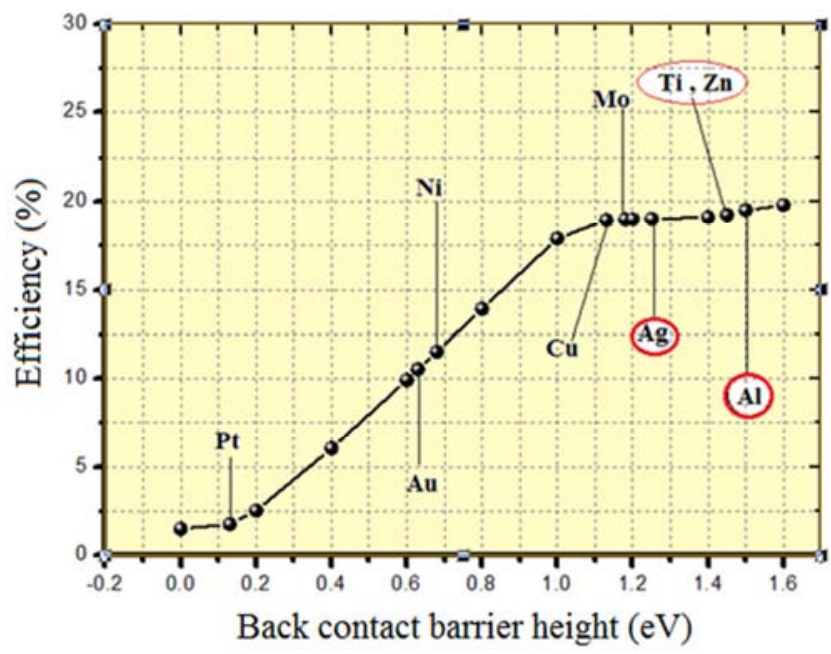

(b)

Figure 7. (a) efficiency with metal work functions, (b) efficiency with back 
contact barrier heights.

Figures 7 (a), (b) and table 2 showed that the metals $\mathrm{Al}, \mathrm{Zn}$, $\mathrm{Ti}, \mathrm{Ag}$, are suitable and make good back contacts to get high efficiencies $19.5 \%, 19.23 \%, 19.23 \%, 19.01 \%$ respectively.

\subsection{Effect of Solar Irradiance and Operating Temperature}

Solar cells experience daily variations in light intensity, with the incident power from the sun varying from ' 0 ' to ' 1 ' $\mathrm{kW} / \mathrm{m}^{2}$, so it is important to investigate the effect of irradiance on solar cell performance with the variation of light intensity [12]. Figure 8 shows how the $I-V$ curves for (glass $/ \mathrm{SnO} \mathrm{O}_{2} / \mathrm{CdS} / \mathrm{CdTe} / \mathrm{Ag}$ ) cell vary with changes in irradiance; the curves move in the vertical direction much more than they move horizontally. When irradiance drops by half, the electricity generated and subsequently solar cell efficiency also reduces by half. The voltage slightly affected by changing irradiance. This result is in a good agreement with the other published works like $[12,15]$.

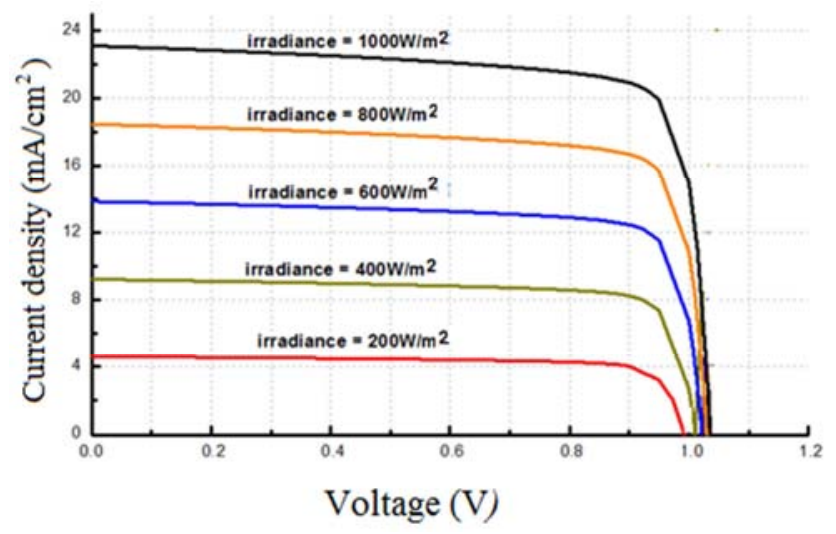

Figure 8. I-V characteristics curves of (glass $/ \mathrm{SnO} \mathrm{O}_{2} / \mathrm{CdS} / \mathrm{CdTe} / \mathrm{Ag}$ ) cell at different irradiance using AMPS-1D simulation program.

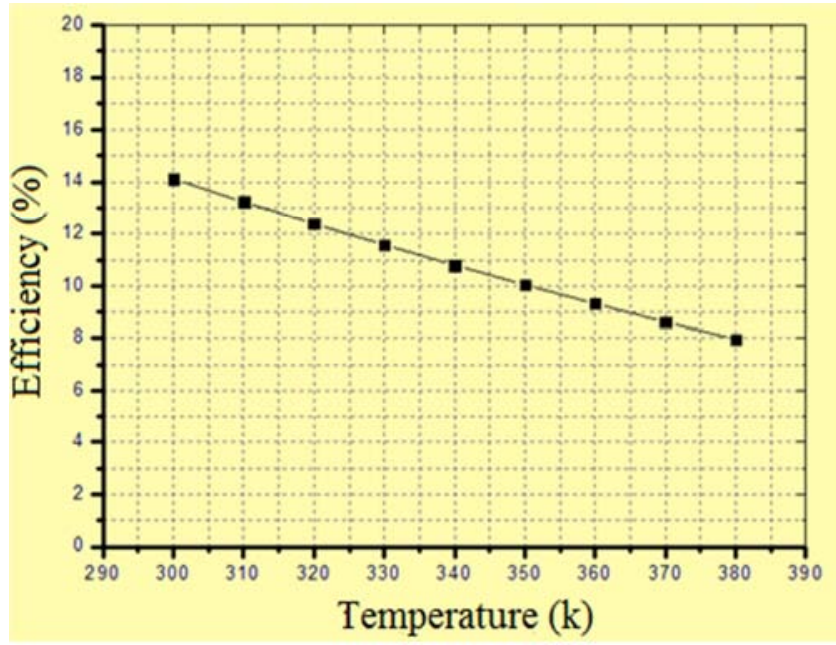

Figure 9. Effect of operating temperature on the cell conversion efficiency.

The relation between the conversion efficiency and operating temperature for the (glass $/ \mathrm{SnO}_{2} / \mathrm{CdS} / \mathrm{CdTe} / \mathrm{Ag}$ ) cell has been studied using AMPS-1D program; the efficiency was calculated as the temperature is changed from $300 \mathrm{~K}(\eta=14.12 \%)$ to 380
$\mathrm{K}(\eta=7.96 \%)$, with $3000 \mathrm{~nm}$ CdTe thickness, $100 \mathrm{~nm} \mathrm{CdS}$ thickness, and $100 \mathrm{~nm} \mathrm{SnO}_{2}$ thickness. The results are shown in figures 9,10 ; it is evident from figure 9 that the conversion efficiency nearly linearly decreases with a rate of $-0.08 \% /{ }^{\circ} \mathrm{C}$, which also indicates the degree of stability of the cell at higher operating temperature. Comparing with the results in the reference [16] for most crystalline and amorphous cells, this cell is more stable. Figure 10 indicates the same results represented by the light I-V characteristics curves.

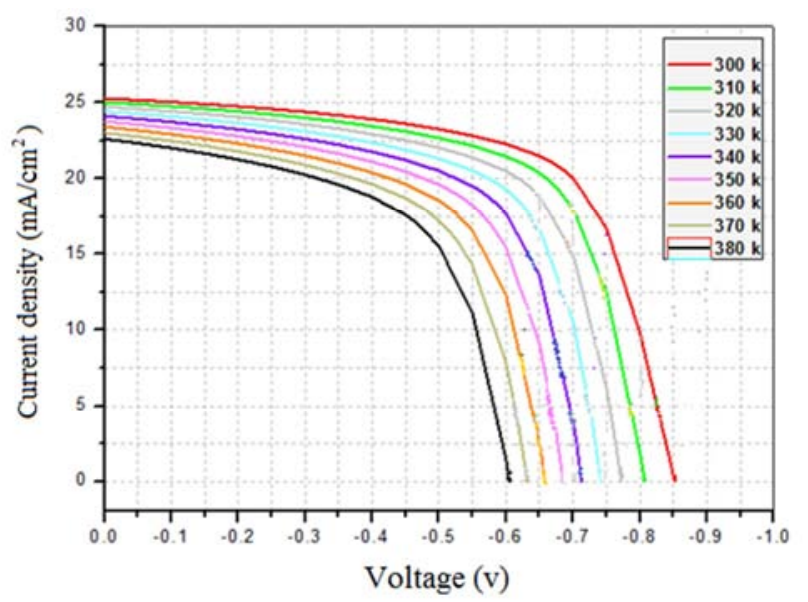

Figure 10. Light I-V characteristics curves for the baseline case cell (glass $\mathrm{SnO}_{2} / \mathrm{CdS} / \mathrm{CdTe} / \mathrm{Ag}$ ) at different operating temperatures.

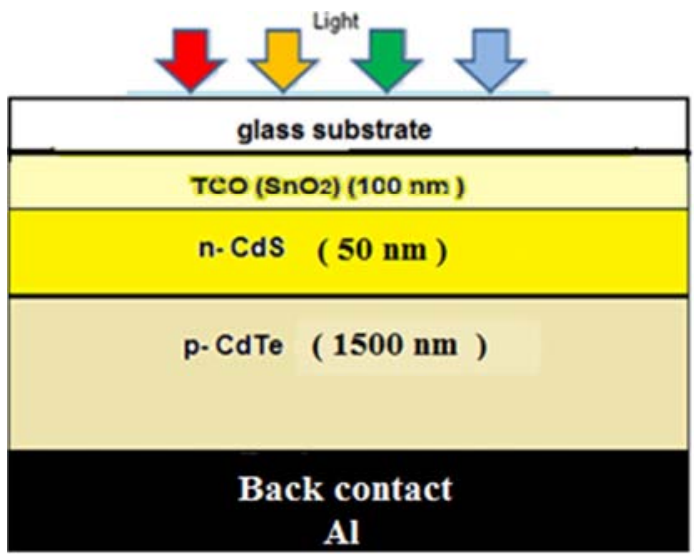

Figure 11. Modified structure for higher performance.

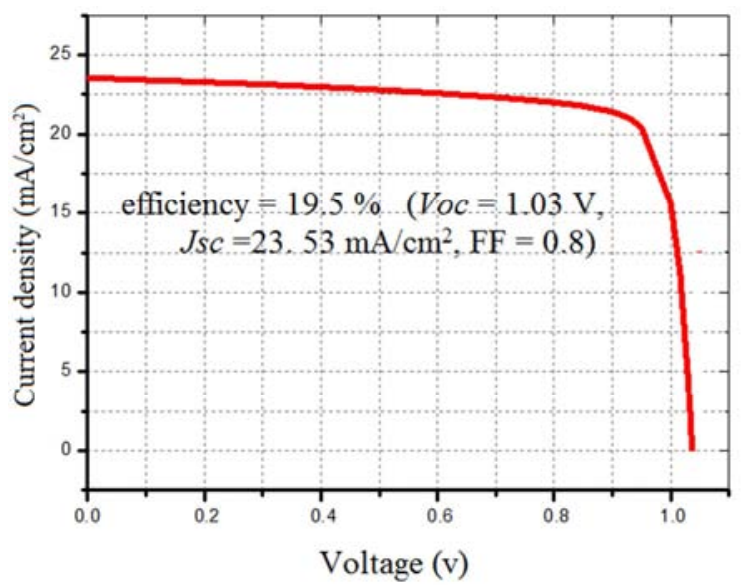


Figure 12. Light I-V Characteristics for the modified structure $\left(\mathrm{SnO}_{2} / \mathrm{CdS} / \mathrm{CdTe} / \mathrm{Al}\right)$ for higher conversion efficiency, where the best parameters values are applied using AMPS-1D program.

Finally we can consider the last results and insert the optimization parameters in the structure (glass $/ \mathrm{SnO}_{2} / \mathrm{CdS} / \mathrm{CdTe} / \mathrm{Al}$ ) which correspond to the best conversion efficiency as was found from the previous results.

In this modified cell the parameters will be fixed as shown in figure 11, with the concentrations $5 \times 10^{16} \mathrm{~cm}^{-3}$ (the today's achievable [11]), $10^{17} \mathrm{~cm}^{-3}$ of $\mathrm{N}_{\mathrm{A}}, \mathrm{N}_{\mathrm{D}}$ respectively, Al metal will be used as a back contact material with back contact barrier height $\left(\Phi_{\mathrm{bL}}\right)$ of $1.5 \mathrm{eV}$; according to this optimization values the high efficiency $19.5 \%\left(V o c=1.03 \mathrm{~V}, J_{S C}=23.53\right.$ $\mathrm{mA} / \mathrm{cm}^{2}$ and $\mathrm{FF}=0.8$ ) has been obtained.

\section{Conclusions}

In this research we have had a simulation study by AMPS1D program on the conversion efficiency of Cadmium Telluride solar cell $\left(\mathrm{SnO}_{2} / \mathrm{CdS} / \mathrm{CdTe}\right)$. A high efficiency $19.5 \%\left(V o c=1.03 \mathrm{~V}, J_{S c}=23.53 \mathrm{~mA} / \mathrm{cm}^{2}, \mathrm{FF}=0.8\right)$ for ultrathin $\mathrm{CdS} / \mathrm{CdTe}$ solar cell has been obtained with $1.5 \mu \mathrm{m}$ of CdTe, $50 \mathrm{~nm}$ of $\mathrm{CdS}, 100 \mathrm{~nm}$ of $\mathrm{SnO}_{2}$, and with the doping concentration of CdTe layer $\left(5 \times 10^{16}\right) \mathrm{cm}^{-3}$, doping concentration of CdS layer $\left(10^{17}\right) \mathrm{cm}^{-3}$, and $(\mathrm{Al})$ as the back contact metal with a barrier height of $1.5 \mathrm{eV}$, when the temperature is fixed at a value of $300 \mathrm{~K}$.

\section{References}

[1] Adirovich, E. I., Yuabov, Y. M. \& Yagudaev, G. R, (1969), Photoelectric effects in film diodes with CdS-CdTe heterojunctions. Sov. Phys. Semicond. 3, 61-64.

[2] Tyan, Y. S., Perez-Albuerne, E. A, (1982), Efficient thin film $\mathrm{CdS} / \mathrm{CdTe}$ solar cells, In: Proceedings of 16th IEEE Photovoltaic Specialists Conference, IEEE Publishing, New York, p. 794.

[3] Ferekides, C., Britt, J., Ma, Y., Killian, L., (1993), High efficiency CdTe solar cells by close spaced sublimation, In: Proceedings of 23 Photovoltaic-specialists -Conference IEEE, New York, USA, p. 389.

[4] J. Britt, C. Ferekides, (1993), 'Thin-film CdS/CdTe solar cell with $15.8 \%$ efficiency'. Applied Physics Lett. 62 (22), 2851.
[5] Xuanzhi Wu., (2004), High-efficiency polycrystalline thinfilm solar cell. Solar Energy (77), 803.

[6] M. Hadrich, C. Kraft, C Loffler, H. Metzner, U. Reislohner, W. Witthuhn. (2009), Pathways to thin absorbers in CdTe solar cells. Thin Solid Films, 517, 2282.

[7] Lukas Kranz, et. Al, (2013), Doping of polycrystalline CdTe for high-efficiency solar cells on flexible metal foil. Nature Communications DOI: 0.1038/ncomms3306.

[8] Hong Z., Ali Kaan Kalkan, Jingya Hou \& Stephen J. Fonash (1999), Application of AMPS-1D for solar cell simulation AIP Conf. Proc., March 5. Osaka, Japan.

[9] M. Barrera, F. Rubinelli, et. al., 25th European Photovoltaic Solar Energy Conference and Exhibition / 5th World Conference on Photovoltaic Energy Conversion, 6-10 September 2010, Valencia, Spain.

[10] M. A. Matin, N. Amine, A. Zaharim, and K. Sopian. A Study towards the Possibility of Ultrathin CdS/CdTe High Efficiency Solar Cells from Numerical Analysis, Wseas Transactions on Environment and Development, ISSN: 1790-5079, Issue 8, Volume 6, August 2010.

[11] N. Amin, M. A. Matin, M. M. Aliyu, M. A. Alghoul, M. R. Karim, and K. Sopian, prospects of Back Surface Field Effect in Ultra-Thin High- Efficiency CdS/CdTe Solar Cells from Numerical Modeling, International Journal of Photoenergy, Article ID 578580, 8 pages, 2010.

[12] M. A. Islam, Y. Sulaiman, N. Amin, (2011), Acomparative study of BSF layers for ultra-thin CdS; O/Cd Te Solar cell, Chalcogenide Lett, Vol. 8, No. 2, P. 65-75.

[13] MD. S. Hossain, N. Amin, M. A. Matin, M. M. Aliyu, T. Razykov, And K. Sopian, (2011), A Numerical Study On The Prospects of High Efficiency Ultrathin $\mathrm{Zn}_{\mathrm{x}} \mathrm{Cd}_{1-\mathrm{x}} \mathrm{S} / \mathrm{CdTe}$ Solar Cell, Chalcogenide Lett., Vol. 8, No. 3, p. 263-272.

[14] T. Ayalew, SiC Semiconductor Devices Technol., Modeling, and simulation, Matr. Nr. 9427747, 2004. http://www.iue.tuwien.ac.at/phd/ayalew/node56.html DOIs: http://www.crossref.org/SimpleTextQuery/

[15] F. Jackson, (2008), Planning and Installing Photovoltaic Systems A guide for installers, architects and engineers second edition, Earthscan, ISBN-13: 978-1-84407-442-6.

[16] E. Skoplaki, J. A. Palyvos, (2009), On the temperature dependence of photovoltaic module electrical performance: A review of efficiency/power correlations. Solar Energy 83, p 614-624. 